\title{
An extremely rare appendiceal anomaly: horseshoe appendicitis
}

\author{
Apendiksin çok nadir bir anomalisi: At nalı apandisit
}

\author{
Cem ORUÇ, ${ }^{1}$ Özgen IŞIK, ${ }^{1}$ Orhan ÜREYEN, ${ }^{1}$ \\ Oytun Saffet KAHYAOĞLU, ${ }^{1}$ Ayhan KÖSEOĞLU ${ }^{2}$
}

\begin{abstract}
Appendiceal anomalies are extremely rare malformations that are usually found in adult populations as an incidental finding. Agenesis and duplication of the appendix have been well documented, but we know of only three reported cases of a horseshoe appendix. A 64-year-old woman admitted to the emergency department. A provisional diagnosis of acute appendicitis was made, and the patient was taken to the operating room. While appendectomy was being performed with a standard approach, the distal tip was seen to communicate with the cecum by another stump, or "horseshoe appendix". The aim of this report is to share our experience with this extraordinary finding.
\end{abstract}

Key Words: Appendix vermiformis; horseshoe; malformation.
Apendiks anomalileri çoğunlukla erişkin popülasyonda rastlantı sonucu bulunan çok nadir malformasyonlardır. Apendiks agenezis ve duplikasyonu iyi bilinmesine rağmen, bildirilmiş sadece üç adet atnalı apendiks olgusu bulunduğunu biliyoruz. Acil servise başvuran 64 yaşında kadın hasta akut apandisit ön tanısı ile ameliyathaneye alındı. Standart yaklaşımla apendektomi uygulanırken, "at nalı apendiks" şeklinde distal ucun ikinci bir güdük ile çekumla bağlantılı olduğu görüldü. Buradaki amac1mız bu sıra dışı bulguyla ilgili deneyimimizi paylaşmaktir.

Anahtar Sözcükler: Appendiks vermiformis; at nalı; malformasyon.
Appendiceal anomalies are extremely rare malformations that are usually found in adult populations as an incidental finding. Agenesis and duplication of the appendix have been well documented, and the incidences for these anomalies are $0.008 \%$ and $0.004 \%$, respectively. ${ }^{[1]}$ However, we know of only three reported cases of a horseshoe appendix..$^{[2-4]}$ In this report, we present the fourth case of a horseshoe appendix.

\section{CASE REPORT}

A 64-year-old woman admitted to the emergency department with a two-day history of right lower abdominal pain, nausea, and loss of appetite. The abdominal examination revealed right lower quadrant tenderness, guarding and rebound tenderness at McBurney's point. All laboratory study results were in normal ranges, and plain chest and abdominal ra- diographs showed no abnormality. Ultrasonographic examination determined pericecal minimal fluid collection. A provisional diagnosis of acute appendicitis was made, and the patient was taken to the operating room. A standard approach was taken with incision over McBurney's point. The cecum was identified, the taenia coli were followed to their confluence, and an appendiceal stump was found. The distal appendiceal tip was seen to extend to the posteromedial cecum, and there were adhesions that complicated mobilization of the appendix. A decision was made to perform retrograde appendectomy. After appendiceal stump and mesoappendix were ligated and divided, the distal tip was seen to communicate with the cecum by another stump, or "horseshoe appendix" (Figs. 1a, b). Appendectomy was completed. The patient made an uneventful recovery and was discharged two days later.

Departments of ${ }^{1}$ General Surgery, ${ }^{2}$ Anesthesiology and Reanimation, İdil State Hospital, Şırnak, Turkey. 


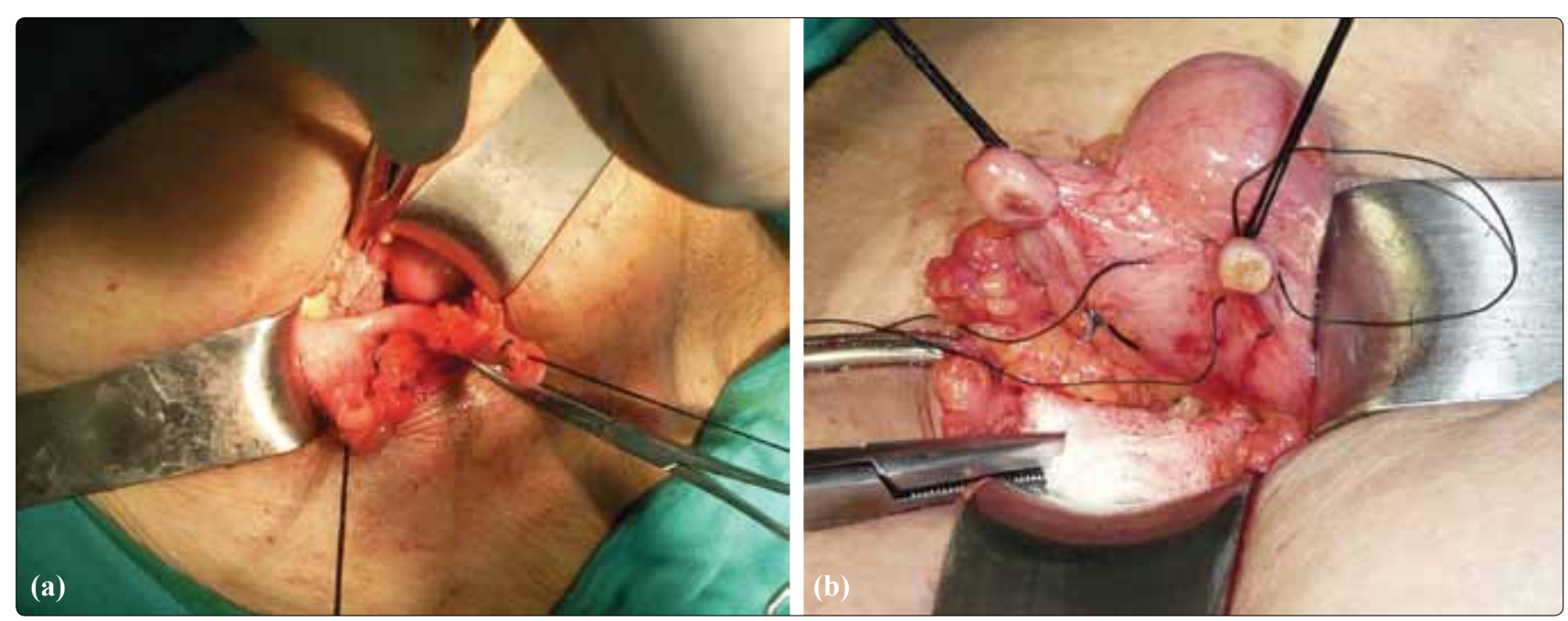

Fig. 1. (a, b) Horseshoe appendix. (Color figure can be viewed in the online issue, which is available at www.tjtes.org).

\section{DISCUSSION}

Appendiceal anomalies are extremely rare malformations. In the study of Collins ${ }^{[1]}$ on 50,000 appendix specimens, there were only four cases of agenesis and two of duplication. Appendiceal duplications were first classified by Cave in 1936 by their anatomical location; this was updated and modified in 1963 by Wallbridge. ${ }^{[3,4]}$ Although several other authors have added further modifications to the classification, it continues to be used for classification of appendiceal duplications only. More recently, cases that do not fit into this classification system have been described as the "horseshoe appendix" or "triple appendix". ${ }^{[5]}$ We thus believe either a new classification system is needed to design appendiceal anomalies, or the present system should be modified. Previously reported horseshoe appendix cases have either been diagnosed during interval appendectomy or found incidentally during abdominal surgery for other reasons. This appendiceal anomaly is likely the result of some unknown embryologic event. Perhaps during embryologic life, the single appendiceal base somehow split in two and become further separated during cecal growth. This might account for just such a double-based, yet single, structure. ${ }^{[2]}$ An appendiceal anomaly can be associated with other congenital abnormalities. ${ }^{[3-5]}$ Preoperative radiological diagnosis of appendiceal anomalies is uncommon. Because of its particular rarity, most surgeons will never encounter a case of horseshoe appendix. It is therefore important that surgical trainees are aware of the anatomical anomalies and malpositions of the appendix.

Conflict-of-interest issues regarding the authorship or article: None declared.

\section{REFERENCES}

1. Collins DC. A study of 50,000 specimens of the human vermiform appendix. Surg Gynecol Obstet 1955;101:437-45.

2. Mesko TW, Lugo R, Breitholtz T. Horseshoe anomaly of the appendix: a previously undescribed entity. Surgery 1989;106:563-6.

3. DasGupta R, Reber PU, Patel AG. Horseshoe appendicitis. Eur J Surg 1999;165:1095-6.

4. Calotă F, Vasile I, Mogoantă S, Zavoi R, Paşalega M, Moraru $\mathrm{E}$, Stoicea C. Horseshoe appendix: a extremely rare anomaly. Chirurgia (Bucur) 2010;105:271-4.

5. Griffiths EA, Jagadeesan J, Fasih T, Mercer-Jones M. Bifid vermiform appendix: a case report. Curr Surg 2006;63:1768 . 